\title{
Evidence of a defensive role for limatulone, a novel triterpene from the intertidal limpet Collisella limatula
}

\author{
Joseph R. Pawlik, Kim F. Albizati* \& D. John Faulkner \\ Scripps Institution of Oceanography, A-012F, La Jolla, California 92093, USA
}

\begin{abstract}
Collisella limatula, a limpet found abundantly in the rocky intertidal from Oregon to Baja California, has recently been found to contain a novel triterpene, limatulone. The present paper describes laboratory experiments and field observations that strongly suggest that limatulone acts as a potent chemical defense against some intertidal predators. Intertidal fish and crabs rejected pieces of the foot of C. limatula, but readily ate the foot tissue of co-occurring gastropods. In contrast, individuals of $C$. limatula were eaten by seastars, an octopus and sea gulls. Fish anti-feedant activity was restricted to a single compound, limatulone, which was present in the foot of the limpet at a mean concentration of $3.5 \mathrm{ppt}$ dry weight. Food pellets containing limatulone at concentrations of $\geq 0.5$ ppt dry weight induced regurgitation in the intertidal fish Gibbonsia elegans, a known limpet predator. Concentrations of limatulone in C. limatula varied from one geographic location to the next and from one mo to the next. Reasons for these variations are not understood. Surveys of the 5 most common limpets in an undisturbed rocky intertidal site revealed that $C$. limatula was the most abundant limpet inside tidepools and on intertidal boulders. Limatulone may act to defend foraging limpets from predatory fishes in tidepools. In the boulder field habitat, shell damage incurred by limpets from wave-borne rocks and debris may expose foot tissue prior to shell regeneration, during which time the chemical defense may release C. limatula from predatory constraints imposed on other intertidal limpets.
\end{abstract}

\section{INTRODUCTION}

Most gastropod molluscs bear a calcified shell which protects the animal from predation and physical injury. Some opisthobranch gastropods, especially nudibranchs, are believed to have lost their shells with a concomitant elaboration of various chemical defense strategies (Thompson 1960, Faulkner \& Ghiselin 1983). These sea slugs are, however, restricted in their distribution to subtidal and cryptic intertidal habitats where physical stresses are reduced.

Limpets are common inhabitants of rocky intertidal shores worldwide and are thus subjected to the combined rigors of desiccation, temperature and salinity fluctuations and pounding by surf, rocks and debris (Southward \& Orton 1954, Dayton 1971, Sousa 1979, Dethier 1984, Shanks \& Wright 1986). Their capshaped shells are adapted for tolerance to high wave energy (Vermeij 1978, Branch \& Marsh 1978), protec-

\footnotetext{
- Present address: Department of Chemistry, Wayne State University, Detroit, Michigan 48202, USA
}

tion from desiccation (Wolcott 1973, Lowell 1984) and wave-borne rock damage (Shanks \& Wright 1986). Despite having a shell, limpets are subject to predation (for review, see Branch 1981) by fishes (Mitchell 1953. Stephens et al. 1970, Cook 1979, Stobbs 1980, Bennett et al. 1983, Garrity \& Levings 1983), seastars (Feder 1963, Mauzey et al. 1968, Branch 1978), crabs (Chapin 1968), octopuses (Wells 1980) and birds (Feare 1971, Hartwick 1976, Lindberg \& Chu 1982).

Recent evidence has suggested that some pulmonate limpets augment the physical defense provided by a shell with a chemical defense against predation. Branch \& Cherry (1985) found that irritated individuals of Siphonaria capensis produce copious amounts of a milky mucus which thwarts predatory gastropods, seastars, fishes and birds. Rice (1985) reported that Trimusculus reticulatus, when agitated, secretes a milky-white mucus which immobilizes the tube feet of attacking seastars and inhibits predation by them. Polypropionate metabolites, some of which are pharmacologically active, have been isolated from 9 species of Siphonaria investigated to date: $S$. 
denticulata (Hochlowski et al. 1983), S. diemenensis (Hochlowski \& Faulkner 1983), S. pectinata (Biskupiak \& Ireland 1983), S. atra, S. zelandica, S. normalis, S. laciniosa (Hochlowski et al. 1984), S. australis (Hochlowski \& Faulkner 1984) and S. lessoni (Capon \& Faulkner 1984), but the ecological consequences of the presence of these compounds in any of these pulmonates has yet to be demonstrated.

Collisella (= Acmaea) limatula, is a prosobranch limpet found abundantly in the rocky intertidal from Oregon to Baja California (Morris et al. 1980). Albizati et al. (1985) have recently demonstrated that $C$. limatula contains a novel triterpene, limatulone, the chemical structure of which is shown in Fig. 1. The present paper is the result of an investigation into the possible ecological importance of limatulone.

\section{MATERIALS AND METHODS}

Biological assays; field experiments. Three or more individuals of each of 3 species of limpets (Collisella limatula, C. scabra and Lottia gigantea) were freshly collected, dissected, and the foot of each diced into $\sim 3 \times 3 \times 3 \mathrm{~mm}$ pieces. Foot pieces were randomly offered to groups of 4 to 10 individuals of each of 2 species of tidepool fishes (juvenile Girella nigricans and Clinocottus analis) found in 2 tidepools near Dike Rock, approximately $1 \mathrm{~km}$ north of Scripps Pier, La Jolla, California (Fig. 2). Food offerings were recorded as having been eaten or, after repeated inspection, abandoned at the bottom of the tidepool.

Biological assays; laboratory experiments. Three or

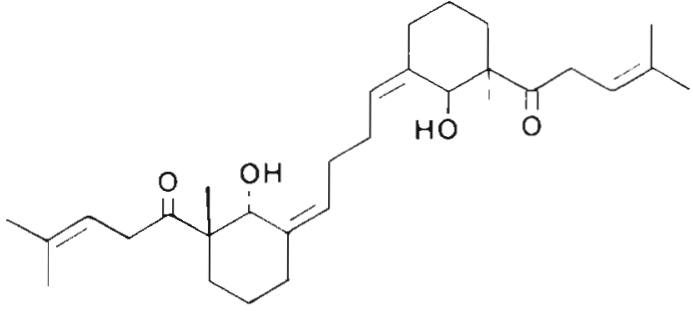

Fig. 1. Structure of the triterpene limatulone, defensive secondary metabolite of the intertidal limpet Collisella limatula (see Albizati et al. 1985)

more individuals of each of 3 species of limpets ( $\mathrm{Col}-$ lisella limatula, C. digitalis and Lottia gigantea) and 1 species of snail (Tegula funebralis) were diced as before and the pieces randomly offered to 2 species of tidepool fishes, 10 individuals of Gibbonsia elegans and 3 individuals of Hypsoblennius gilberti, housed in individual compartments in laboratory aquaria. Food offerings were presented to fish in a pipette at the top of the compartrnent; normal consumption of a food offering was followed by normal respiratory movements, while rejection of a food offering involved flaring of the gill covers and subsequent regurgitation of the ingested piece.

Experiments with the hermit crab Pagurus samuelis entailed placing a $\sim 4 \times 4 \times 4 \mathrm{~mm}$ piece of foot tissue from each of the 2 limpets Collisella limatula and Lottia gigantea together in the middle of a $250 \mathrm{ml}$ finger bowl along with a single crab $(20$ crabs used in assay). The type of foot tissue initially held in the claws of the crab, and the type held 10 min thereafter was

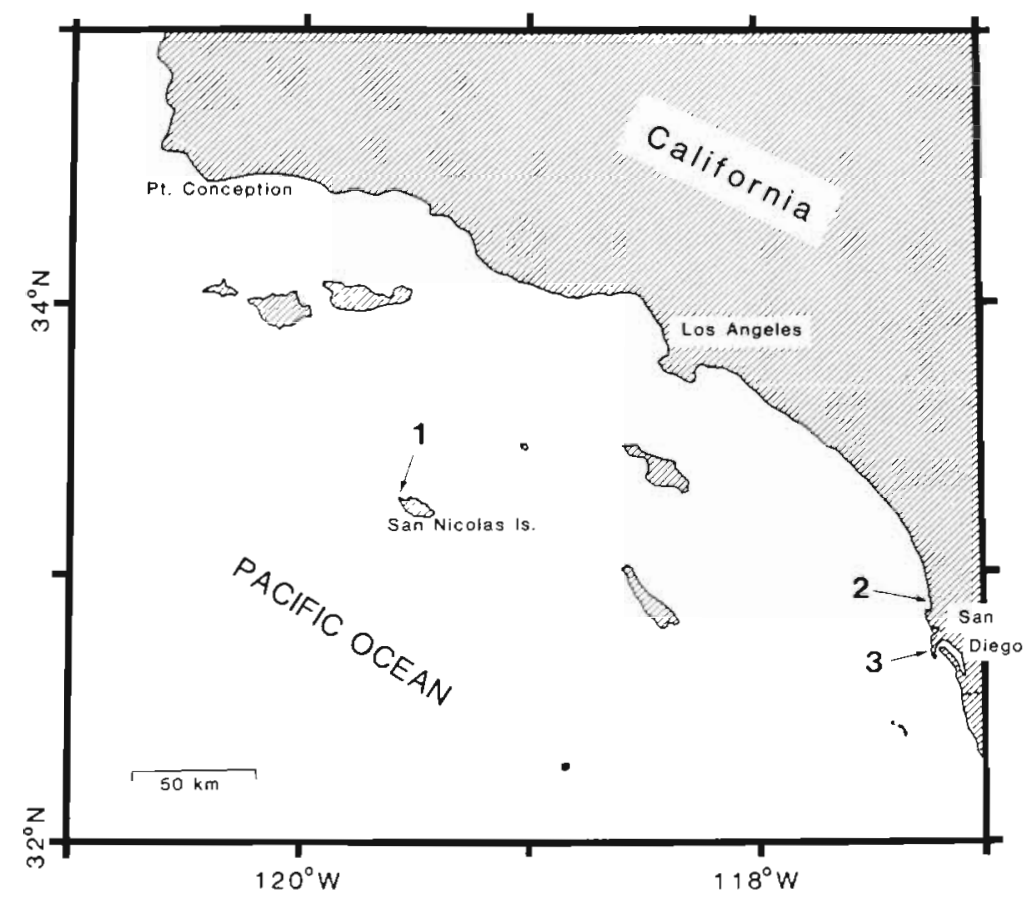

Fig. 2. Limpet collection and study sites in California. (1) Northwest point of San Nicolas Island. (2) Dike Rock, La Jolla. (3) Sunset Cliffs, Ladera Street, Point Loma, San Diego 
recorded (foot tissue of C. limatula is pale yellow, that of L. gigantea is white).

Whole, similarly-sized, overturned individuals of Collisella limatula and Lottia gigantea were randomly added to aquaria containing individual intertidal seastars, 2 each of Pisaster giganteus and Astrometis sertulifera, and the results recorded after $24 \mathrm{~h}$. Whole limpets were similarly offered to an octopus (Octopus sp.). Whole foot pieces of C. Limatula and L. gigantea were randomly offered to 2 captive California sea gulls (Larus californicus) that had been starved for $12 \mathrm{~h}$ preceding the assay; their responses to the food offerings were recorded.

Extracts of freeze-dried Collisella limatula (see below) were used in feeding assays performed on the spotted kelpfish Gibbonsia elegans. Extracts were dissolved in their respective solvents and injected into freeze-dried krill pellets (Euphausiasp., San Francisco Bay Brand Ocean Plankton, approximately $4 \mathrm{mg}$ each) so as to saturate each pellet at 100 ppt pellet dry weight, thereafter the pellets were dried under nitrogen. Experimental pellets and control pellets treated with solvent alone (paired) were randomly fed to fish, with the responses recorded as previously described. The assay was repeated with purified limatulone at $5.0,1.0,0.5$ and $0.1 \mathrm{ppt}$ dry weight of pellet.

Where applicable, the non-parametric G-test of goodness of fit (hermit crab assay) or the G-test of independence (all others) was employed to ascertain significance of the difference between frequency distributions (Sokal \& Rohlf 1981).

Extraction of limpets and isolation of limatulone. Freeze-dried Collisella limatula (about 400) were extracted sequentially in hexane, diethyl ether, ethyl acetate and methanol, and the extracts assayed for inhibition of fish feeding. The combined hexane and diethyl ether soluble extracts were fractionated by flash chromatography (Still et al. 1978) on silica gel (E. Merck, 230 to 400 mesh) with eluants of increasing polarity from $100 \%$ hexane to $100 \%$ diethyl ether. The active component, limatulone (Fig, 1), was eluted in the $100 \%$ diethyl ether fraction ( 95 to $99 \%$ purity). Final purification of limatulone was achieved by highperformance liquid chromatography on Partisil with $60 \%$ hexane: $40 \%$ ethyl acetate as eluant. The structural determination of limatulone has been previously described (Albizati et al. 1985). In the present study, analysis for limatulone relied on thin-layer chromatography against a purified standard together with ${ }^{1} \mathrm{H}$ nuclear magnetic resonance spectroscopy.

The localization of limatulone in the limpet was determined in the following manner: pedal mucus was transferred from the foot of each of 100 limpets onto filter paper. The limpets and filter paper were freezedried and the limpets dissected into 3 parts (shell, viscera and foot). Shells, visceral masses, foot tissue and the pedal mucus on filter paper were each separately extracted and analyzed for limatulone.

In an attempt to isolate limatulone from the algal diet of the limpet, rocks covered with enrusting red algae of the genera Hildenbrandia, Peyssonelia, Lithothamnion and Lithophyllum, algae upon which C. limatula are known to feed (Eaton 1968, J. R. Pawlik unpubl. obs.), were extracted and analyzed for limatulone.

Bimonthly determination of limatulone concentrations. The levels of limatulone in limpet foot tissue were quantified for Collisella limatula collected from Dike Rock $(1.1 \mathrm{~km}$ north of Scripps Pier, La Jolla, California), Sunset Cliffs (Ladera Street, Point Loma, San Diego, California) and San Nicolas Island (N. W. side, Fig. 2) from June 1984, through October 1985. For each collection, 90 to 100 limpets were frozen, freezedried and dissected into 3 parts (shell, visceral mass and foot). The parts were weighed, individual shell lengths measured, shells checked for evidence of repair and limatulone quantitatively isolated from the foot tissue.

Field surveys. Field transects were carried out in the lower intertidal at San Nicolas Island, where the intertidal environment is free of human interference. Two adjacent sites on the N.W. side of the island were surveyed (Fig. 2). They consisted of (1) an intertidal boulder field, approximately $100 \mathrm{~m}$ in length, composed of large (1 to $3 \mathrm{~m}$ ) boulders interspersed with sand and cobbles, and (2) a rock shelf outcrop, approximately $50 \mathrm{~m}$ in length, pitted with large (2 to $4 \mathrm{~m}$ diameter, irregular) tidepools.

At the boulder site, 8 similarly shaped boulders with approximately equal surface areas were randomly selected and the number of each species of limpet counted, dividing the count into limpets on the seaward side (mostly vertical plane facing the water), landward side (mostly vertical plane facing the land), and top (mostly horizontal plane) of each boulder. At the tidepool site, 4 pools were haphazardly chosen, a grid was established and 5 random $0.25 \times 0.25 \mathrm{~m}$ quadrat samples were taken. The number of each limpet species was counted within each quadrat sample.

\section{RESULTS}

\section{Biological assays}

The results of biological assays on whole and dissected limpets are presented in Table 1. Adult sculpins Clinocottus analis and juvenile opaleye Girella nigricans promptly ate small pieces of the foot of Collisella scabra and Lottia gigantea, but refused pieces of the 
Table 1. Collisella limatula. Feeding responses of intertidal predators to $C$. Limatula and alternative sympatric gastropods. $T=$ tidepool assay, $\mathrm{L}=$ laboratory assay; $\mathrm{P}=$ foot pieces assayed, $\mathrm{W}=$ whole limpet assayed, $F=$ whole foot assayed. Except for hermit crab assay, number in replicates column is the number of randomized, paired comparisons of the response of assay predators to the foot of $C$. limatula versus the foot of the listed alternative gastropods. $E / C$ is the number of $C$. limatula foot offerings eaten/number of alternative gastropod foot offerings eaten. For hermit crab assay, the number in the replicates column is the number of times the choice experiment was run; $E / C$ is the number of crabs holding C. limatula/alternative gastropod foot pieces after $10 \mathrm{~min}$

\begin{tabular}{|c|c|c|c|c|c|}
\hline $\begin{array}{l}\text { Potential } \\
\text { predator }\end{array}$ & Common name & $\begin{array}{l}\text { Alternative gastropod } \\
\text { tested }\end{array}$ & $\begin{array}{l}\text { Experimental } \\
\text { conditions }\end{array}$ & $\begin{array}{l}\text { Repli- } \\
\text { cates }\end{array}$ & $\mathrm{E} / \mathrm{C}$ \\
\hline Girella nigricans & Opaleye & $\begin{array}{l}\text { Lottia gigantea } \\
\text { Collisella scabra }\end{array}$ & $\mathrm{T} / \mathrm{P}$ & 15 & $0 / 15^{\circ}$ \\
\hline Clinocottus analis & Woolly sculpin & $\begin{array}{l}\text { L. gigantea } \\
\text { C. scabra }\end{array}$ & $\mathrm{T} / \mathrm{P}$ & 7 & $0 / 7$ \\
\hline Gibbonsia elegans & Spotted kelpfish & $\begin{array}{l}\text { L. gigantea } \\
\text { C. digitalis } \\
\text { Tegula funebralis }\end{array}$ & $L / P$ & 21 & $0 / 21^{\circ}$ \\
\hline Hypsoblennius gilberti & Notchbrow blenny & $\begin{array}{l}\text { L. gigantea } \\
\text { C. scabra } \\
\text { T. funebralis }\end{array}$ & $\mathrm{L} / \mathrm{P}$ & 18 & $3 / 18^{\circ}$ \\
\hline Pagurus samuelis & Hermit crab & L. gigantea & $\mathrm{L} / \mathrm{P}$ & 56 & $10 / 46^{\circ}$ \\
\hline Pisaster giganteus & Knobby seastar & L. gigantea & $\mathrm{L} / \mathrm{W}$ & 4 & 44 \\
\hline Astrometis sertulifera & Soft seastar & L. gigantea & $\mathrm{L} / \mathrm{W}$ & 4 & $4 / 4$ \\
\hline Octopussp. & Octopus & L. gigantea & $\mathrm{L} / \mathrm{W}$ & 3 & $3: 3$ \\
\hline Larus californicus & Sea gull & L. gigantea & $L / F$ & 6 & $6 / 6$ \\
\hline
\end{tabular}

foot of C. limatula. In laboratory experiments, the common tidepool fishes Gibbonsia elegans and Hypsoblennius gilberti, both known limpet predators (Mitchell 1953, Stephens et al. 1970), rejected the pedal tissue of $C$. limatula, although pieces of the foot of cooccurring gastropods were eaten. Both species of fish readily ate pieces and whole portions of the visceral mass dissected from C. limatula.

In 56 choice experiments with the hermit crab Pagurus samuelis, pieces of the foot of Collisella limatula were held by 24 crabs and pieces of the alternative limpet were held by 32 crabs at the onset of the experiment; after $10 \mathrm{~min}, 10 \mathrm{crabs}$ held $C$. limatula and 46 held the alternative limpet. The final frequency distribution was significantly different from both a random distribution and from the distribution at the onset of the experiment (G-test, $\mathrm{p}<0.005$ ).

Intertidal seastars Astrometis sertulifera and Pisaster giganteus readily consumed whole, overturned limpets, including Collisella limatula. Moreover, the foot tissue of both $C$. limatula and Lottia gigantea was eaten by an octopus and by captive California sea gulls Larus californicus.

Only the hexane and diethyl ether soluble extracts of whole Collisella limatula inhibited fish feeding. Separation of the active component of these extracts yielded limatulone, which induced regurgitation in Gibbonsia elegans at concentrations as low as $0.5 \mathrm{ppt}$ dry weight of food pellet (Table 2).
Table 2. Cibbonsia elegans. Feeding responses of an intertidal predatory fish to food pellets containing limatulone. $N=$ the number of randomized, paired comparisons of control and treated pellets. L/C is the number of limatulone-treated pellets eaten/number of control pellets eaten

\begin{tabular}{|ccc|}
$\begin{array}{c}\text { Limatulone } \\
\text { concentration } \\
\mathrm{ppt}\end{array}$ & $\mathrm{N}$ & $\mathrm{L} / \mathrm{C}$ \\
\hline 5.0 & 10 & $0 / 10^{\cdots}$ \\
1.0 & 10 & $0 / 10^{\cdots}$ \\
0.5 & 10 & $0 / 10^{\cdots}$ \\
0.1 & 10 & $9 / 10$ \\
& & \\
$\cdots$ Per dry weight of food pellet & \\
\hline p < 0.05, G-test & \\
\hline
\end{tabular}

\section{Extraction of limpets and isolation of limatulone}

Limatulone was found in the foot of Collisella limatula, but not in the shell, visceral mass, or pedal mucus. The mean concentration of limatulone was 3.5 ppt dry weight of the foot ( $\mathrm{N}=18$ collections of 90 to 100 limpets, $\mathrm{SD}=0.99 \mathrm{ppt}$, range $=1.9$ to $5.2 \mathrm{ppt}$ ). Limatulone was not found in extracts of rocks covered with encrusting red algae of the genera Hildenbrandia, Peyssonelia, Lithothamnion and Lithophyllum. 

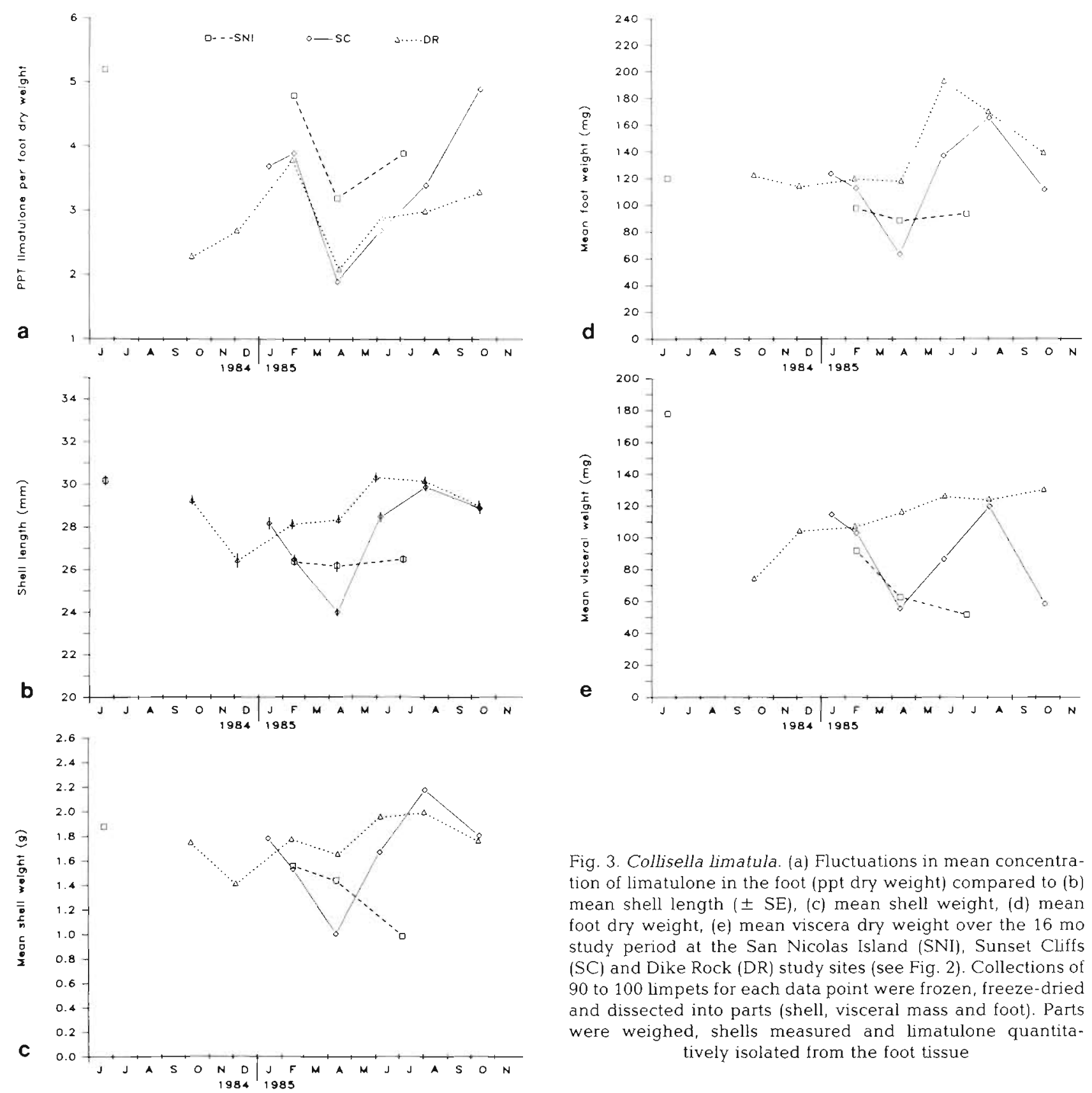

Fig. 3. Collisella limatula. (a) Fluctuations in mean concentration of limatulone in the foot (ppt dry weight) compared to (b) mean shell length ( $\pm S E$ ), (c) mean shell weight, (d) mean foot dry weight, (e) mean viscera dry weight over the 16 mo study period at the San Nicolas Island (SNI), Sunset Cliffs (SC) and Dike Rock (DR) study sites (see Fig. 2). Collections of 90 to 100 limpets for each data point were frozen, freeze-dried and dissected into parts (shell, visceral mass and foot). Parts were weighed, shells measured and limatulone quantitatively isolated trom the foot tissue

\section{Bimonthly determination of limatulone concentration}

The concentration of limatulone was greater in Collisella limatula from San Nicolas Island than in limpets from the 2 collection sites near San Diego for contemporaneous collections from the 3 sites (Fig. 3a). Levels of limatulone in the foot tissue of limpets from all 3 sites showed similar fluctuations over the course of the sampling period; most notably, a drop in limatulone concentration for the April 1985 collections. The same concentration of limatulone was found in the foot of

limpets from both the boulder field and tidepool habitats of San Nicolas Island based on 2 separate collections: one from February, the other from July, 1985. Recovery of limatulone from the foot of $C$. limatula with the outlined extraction procedure proved to be highly reproducible in a limited number of replicates. With the possible exception of C. limatula from the Sunset Cliffs collection site, the fluctuations in limatulone concentration did not appear to follow trends in mean shell size or weight, or mean freezedried viscera or foot weight (Fig. $3 \mathrm{~b}$ to e). 
At the San Nicolas Island site, shell heights of Collisella limatula from the boulder field were significantly greater than those of their conspecifics in tidepools (Fig. 4). The most commonly observed type of shell damage was 'skirt' formation (Fig. 5c, d), with a concentric, marginal growth of more recently accreted shell material around an apical 'cap'. Of 1751 specimens of C. limatula collected during the present study, $30 \%$ showed skirt formation, with obvious variation between collection sites: $34.0 \%$ of 288 limpets collected from the San Nicolas Island boulder field had suffered concentric marginal damage, whereas only $4.4 \%$ of 137 limpets from the tidepools showed similar damage.

Collisella limatula from the Sunset Cliffs site were collected from a high-energy boulder field similar to that found on San Nicolas Island: $39.0 \%$ of 934 limpets collected there exhibited skirt formation. The Dike Rock population of C. limatula inhabited boulders on the shoreward side of a rock reef that bore the brunt of wave energy: $14.5 \%$ of 392 limpets collected from that site showed evidence of margin regeneration.

\section{Field surveys}

Collisella limatula was the most abundant limpet on boulders, with nearly twice as many individuals as the next most abundant limpet, C. scabra (Fig. 6a). C. Iimatula was found predominantly on the sides of the boulders, especially on the seaward side, with $C$. scabra, C. digitalis and Lottia gigantea predominating on the top surface. At the tidepool site, C. limatula was found almost exclusively submerged in tidepools, whereas the other limpets sampled were found almost exclusively outside tidepools (Fig. 6b). C. scabra was the most abundant limpet at the tidepool site, followed closely by $C$. limatula.

\section{DISCUSSION}

In laboratory assays, limatulone is a highly potent inhibitor of fish feeding - nearly 10 times more effective on a dry weight basis at inducing regurgitation than polygodial, a defensive compound isolated from nudibranchs (Cimino et al. 1982, Okuda et al. 1983). Although effective against fish and crab predators, limatulone had no apparent effect on seastars, octopuses or sea gulls. This would imply that Collisella limatula may be vulnerable to these predators. However, $C$. limatula has a characteristic behavioral avoidance response upon contact with, or in the presence of, predatory seastars (Bullock 1953, Feder 1963, Phillips 1975, 1976), and Wells (1980) concluded that C. limatula avoided octopus predation by remaining inactive and inconspicuous when awash during daylight hours. Black oyster catchers Haematopus spp. prey on limpets (Hartwick 1976, Branch \& Cherry 1985), and sea gulls may have some impact (Lindberg $\&$ Chu 1982), although the overall importance of seabird predation on intertidal gastropods is thought to be minor in comparison to that caused by marine organisms (Bertness et al. 1981 and references therein).

Limatulone was found only in the foot of Collisella limatula, not in the pedal mucus, viscera or shell. Some intertidal pulmonates possess defensive mucoid secretions, including onchiids (Ireland \& Faulkner 1978) and siphonariid limpets (Branch \& Cherry 1985, Rice 1985, D. J. Faulkner unpubl. obs.). C. limatula, a prosobranch, does not exude limatulone into its pedal mucus, yet the avoidance response of potential pre-

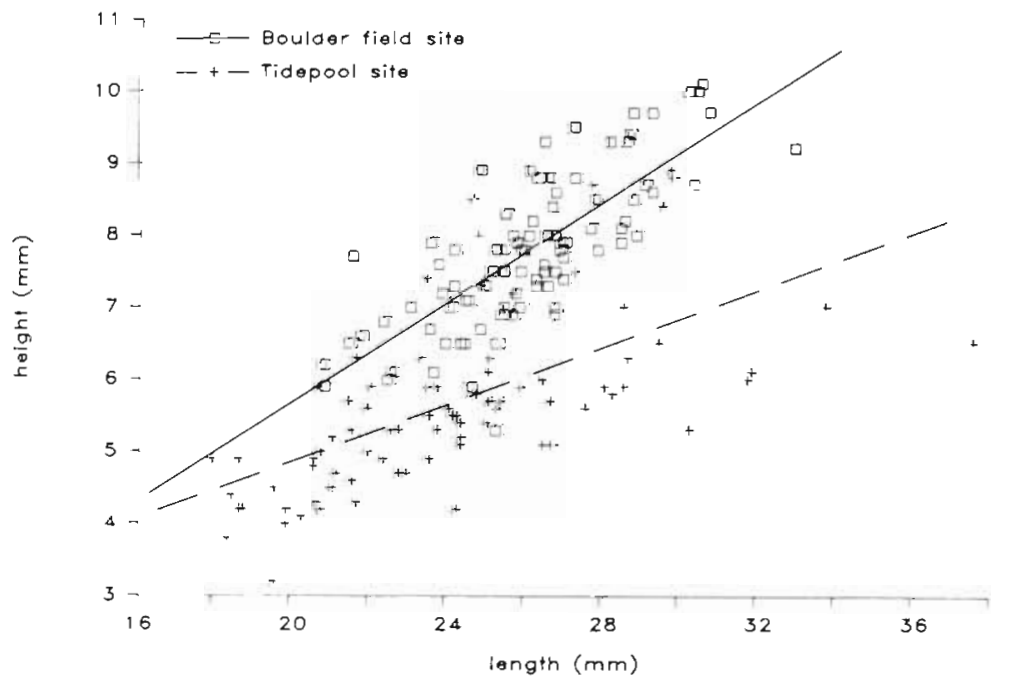

Fig. 4. Collisella limatula. Scatter plot of shell length versus shell height for specimens from tidepool site and boulder field site in the intertidal of San Nicolas Island. Linear regression equations $(y=$ shell height $(\mathrm{mm}), x=$ shell length $(\mathrm{mm})), y=0.34 x-1.20$ (boulder field site, $N=92$ ); $y=0.20 x+0.84$ (tidepool site, $N=81$ ). Analysis of covariance indicates a significant difference in shell height between the 2 sites when shell length is held constant $\left(p<0.001, F_{s}=158.9, \mathrm{df}=1,170 ;\right.$ Sokal \& Rohlf $1981)$ 

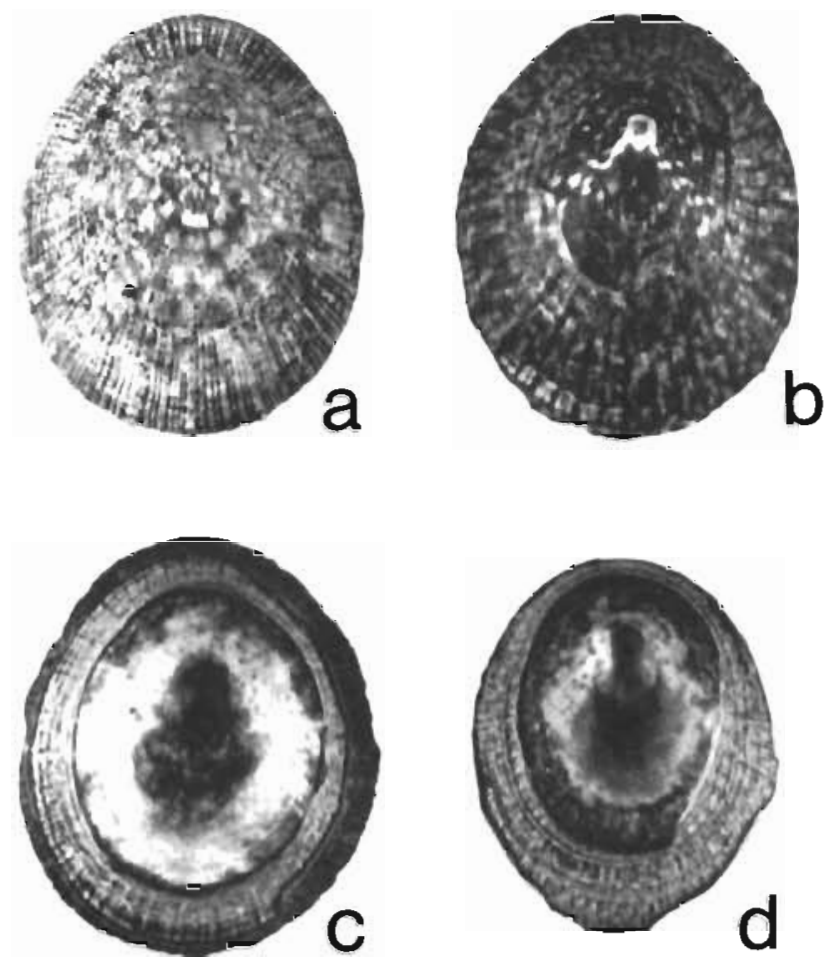

Fig. 5. Collisella limatula. (a) Shells collected from inside a tidepool, San Nicolas Island. Shel] height is 0.4 times the height of the shell in (c). Note the radiating ridges - absence of shell wear. (b) Shell collected from boulder field site, San Nicolas lsland. No obvious shell damage. Note the scoured-smooth appearance. (c) Shell collected from boulder field site, San Nicolas Island. Note multiple 'skirt' formation. (d) shell collected from boulders at Sunset Cliffs site. Note 'skirt' formation. (e) Shell margin broken from a shell of $C$. limatula in the laboratory by artificial impact - shell apex was left intact. (f) Shell margin found among boulders at Sunset Cliffs site
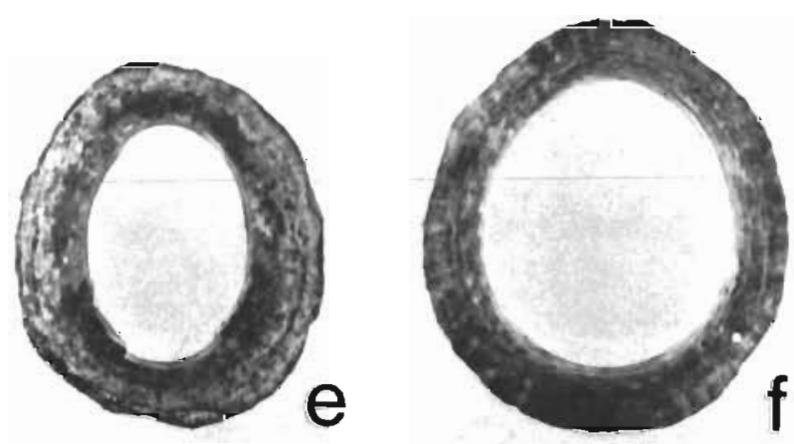

dators is similarly immediate and dramatic. Tidepool fishes were never observed to make repeated attacks on overturned C. limatula (as they do with other limpet species), and attacks that were made resulted in no apparent harm to the limpet. Limatulone may be released directly from the foot as the limpet is attacked. C. limatula appears to avoid the expense of secreting a chemical defense along with its pedal mucus, a substance that is produced in copious amounts during gastropod locomotion (Calow 1974, Denny 1980).

The absence of limatulone in the visceral mass of Collisella limatula suggests that the compound is not directly derived from the diet, corroborated by the absence of limatulone in extracts of rocks covered with the encrusting red algae preferred by these limpets
(Eaton 1968). It seems most likely that limatulone is synthesized by $C$. limatula, probably from related but inactive dietary precursors.

There are many potential explanations for the variation in the concentration of limatulone in the foot of Collisella limatula collected from San Nicolas Island versus those collected near San Diego, and for seasonal variation at all 3 study sites. If algal precursors are necessary for the synthesis of limatulone, the algae may show variations in their local or temporal abundance or chemical constitution. The levels of limatulone were the same for both limpets collected from within tidepools and on boulders at San Nicolas Island, even though the abundance of encrusting red algae was much greater within the pools. Other dietary algae may be important in precursor production. 

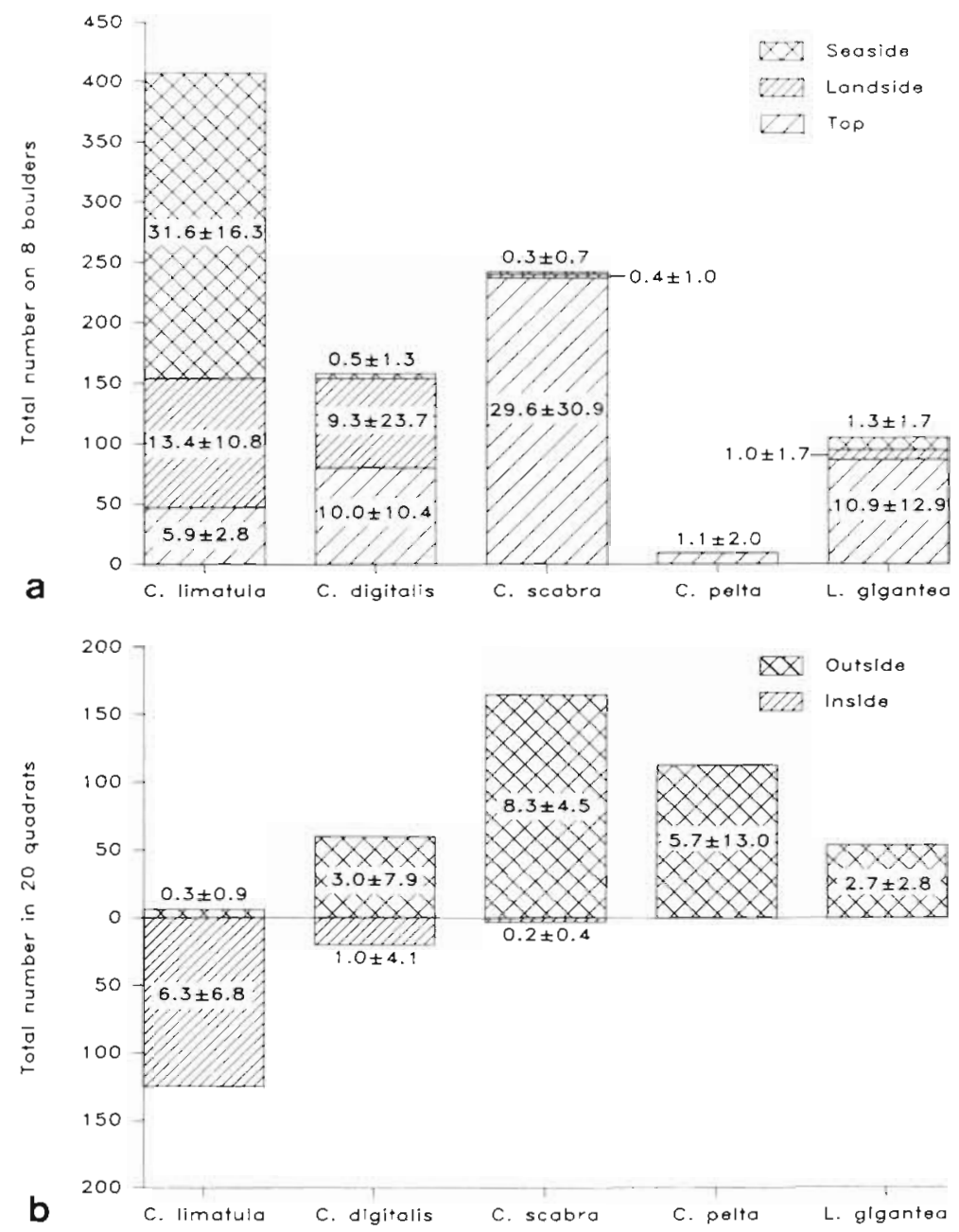

Fig. 6. Distribution and abundance of limpets in the mid-intertidal of San Nicolas Island. (a) Total number of Collisella limatula, C. digitalis, $C$. scabra, C. pelta, and Lottia gigantea on 8 randomly selected boulders in an intertidal boulder field. Samples were subdivided into limpots occupying the seaward side, landward side and tops of boulders surveyed. Mean and standard deviation for each category is shown. (b) Total number of C. limatula, C. digitalis, C. scabra, C. pelta, and $L$. gigantea within a total of 20 randomly sampled quadrats $(0.25 \times 0.25 \mathrm{~m})$, both outside and inside (submerged at low tide) a total of 4 tidepools (5 samples outside and inside of each pool) at a rocky tidepool site. Mean and standard deviation for each category is shown

The non-feeding planktonic larvae of Collisella limatula are competent to settle and metamorphose after 4 to $5 \mathrm{~d}$, but can remain healthy and settle many weeks thereafter (D. R. Lindberg pers. comm.). It seems unlikely that genetic variation between San Nicolas Island and San Diego populations could explain the difference in the concentration of limatulone between limpets at the 2 sites. Predation pressure could be higher at the San Nicolas Island site, resulting in differential survival of limpets with higher levels of limatulone in their foot tissues.

Temporal variation may be a function of the reproductive state of the limpets. This does not, however, seem to be reflected in the mean visceral weight over time. Seapy (1966) found that at least $50 \%$ of the population of Collisella limatula he studied was ripe for spawning throughout much of the year, and spawning occurred during fall, winter and spring. Seasonal fluctuations in the levels of limatulone in $C$. limatula merit further study.

The field survey reveals that Collisella limatula was the most abundant limpet in 2 very different intertidal habitats: inside tidepools and on exposed boulders. Limpets inside tide pools were continuously submerged and were surrounded by an abundance of encrusting red algae. The shells from $C$. limatula in tidepools were flatter than the shells of conspecifics living on boulders (Fig. 4 and discussion below), and rarely showed evidence of repaired damage. $C$. limatula, along with the other limpets surveyed, were inactive when not submerged or awash during daylight hours, as similarly observed by Eaton (1968) and Wells (1980). Contrary to Wells (1980), however, $C$. limatula that were continuously submerged in tidepools actively foraged during daylight hours; in contrast, the small number of $C$. digitalis found in the pools appeared inactive. Several southern California tidepool fishes are known to feed on acmaeiid limpets (Mitchell 1953, Johnston 1954, Stephens et al. 1970). In particular, the kelpfish Gibbonsia elegans was found to be the most abundant of 22 species of tidepool fishes in a survey by Mitchell (1953). It seems likely that, within the tidepool habitat, limatulone may protect $C$. limatula from predation by both fishes and crabs, 
allowing utilization of a food source unavailable to the other limpet species.

Apart from emersion between tides, the boulder field habitat contrasted with the tidepool habitat in several respects. The sand and cobble-scoured boulders were free of macro-algae; limpets feed on microscopic algae on the rock surface (Eaton 1968). During low tides, individual Collisella limatula were not confined to crevices or the undersides of rocks, as reported by Wells (1980), but were fully exposed on the sides of boulders where wave backwash, scouring by sand, and impact by cobbles were most intense. The intensity of physical disturbance was reflected in the levels of shell damage found in the limpet collections from the 3 sites, with the highest levels of skirt formation among limpets collected from the Sunset Cliffs and San Nicolas Island boulder fields. Bulkley (1968) reported that this type of shell damage was exhibited by $81 \%$ of 32 specimens of $C$. limatula he collected. Repetitive shell margin breakage and regeneration among $C$. limatula living in high-energy habitats is a likely cause of the greater shell height exhibited by these limpets (Fig. 4).

Chapin (1968) noted that approximately $14 \%$ of the shells of Collisella limatula cast up on the beach consisted solely of the shell margin or 'skirt'. He found that shells were easily broken along the concentric muscle scar of the shell and concluded that such breakage was the result of predation by the shore crab Pachygrapsus crassipes. We have similarly observed shell margins of C. limatula among intertidal rocks and sand (Fig. 5f). Shanks \& Wright (1986) have recently attributed the high incidence of shell margin damage and regeneration in $C$. limatula to impact by wave-borne rocks. They suggest that $C$. limatula has evolved shells that break in order to absorb impact energy. Their analysis is supported by the variation in shell damage observed in the present study. A limpet with a damaged or missing shell margin would have a considerable portion of its foot exposed to predators. The presence of the defensive chemical limatulone may serve to protect the exposed foot of the limpet while the shell regenerates. Therefore, in C. limatula, the evolution of nonfatal shell breakage as a device for surviving rock or wave impact, as suggested by Shanks \& Wright (1986), may have arisen only after the acquisition of an effective chemical defense.

The 2 most abundant limpet species along the coast of southern California, Collisella scabra and $C$. limatula, exhibit very different survival strategies. $C$. scabra homes to a scar (Wells 1980), a behavior thought to reduce mortality as a result of desiccation (Lowell 1984, Branch \& Cherry 1985), predation (Frank 1981, Garrity \& Levings 1983), competition, wave action and sand abrasion (see Branch 1981 for review). C. scabra was most abundant on the top surfaces of boulders at the boulder field site and outside tidepools at the tidepool site (Fig. 4), where desiccation might exlude non-homing limpets (Wolcott 1973). In contrast, the present work strongly suggests that $C$. limatula, a species that does not home to a scar (Wells 1980, J. R. Pawlik unpubl. obs.), relies on a chemical defense which inhibits fish predation while these limpets actively forage in tidepools. In addition, non-fatal shell breakage, combined with the chemical defense, would permit survival of $C$. Limatula on the sides of intertidal boulders where the incidence of waveborne rock damage is particularly high.

Acknowledgements. The authors thank W. G. Wright and A. L. Shanks for preliminary observations, advice and criticism. M. R. Amieva, M. K. Harper, C. B. Rose, M. Kelly, P. A. Leong, R. J. Pawlik, S. J. Pawlik, G. VanBlaricom and J. VanderWier helped with limpet collection. M. R. Amieva assisted with bioassays and D. Fields with field surveys. N. D. Holland critically reviewed the manuscript. Sea gulls were provided by M. A. Faulkner (Project Wildlife, San Diego). Access to San Nicolas Island was provided through $W$. G. Wright by the staff of the U. S. Naval Pacific Missile Test Center, Point Mugu, California. This research was supported by NSF Grant CHE81-21471, NSF predoctoral fellowship to J.R.P., and NIH postdoctoral fellowship CA07458-02 to K.F.A.

\section{LITERATURE CITED}

Albizati, K. F., Pawlik, J. R., Faulkner, D. J. (1985). Limatulone, a potent defensive metabolite of the intertidal limpet Collisella limatula. J. org. Chem. 50: 3428-3430

Bennett, B., Griffiths, C. L., Penrith, M.-L. (1983). The diets of littoral fish from the Cape Peninsula. S. Afr. J. Zool. 18: 343-352

Bertness, M. D., Garrity, S. D., Levings, S. D. (1981). Predation pressure and gastropod foraging: a tropical-temperate comparison. Evolution 35: 995-1007

Biskupiak, J. E., Ireland, C. M. (1983). Pectinatone, a new antibiotic from the mollusc Siphonaria pectinata. Tetrahedron Lett. 24: 3055-3058

Branch, G. M. (1978). The responses of South African patellid limpets to invertebrate predators. Zool. Afr 13: 221-232

Branch, G. M. (1981). The biology of limpets: physical factors, energy flow and ecological interactions. Oceanogr. mar. Biol. A. Rev. 19: 235-379

Branch, G. M., Cherry, M. I. (1985). Activity rhythms of the pulmonate limpet Siphonaria capensis Q. \& G. as an adaptation to osmotic stress, predation and wave action. J. exp. mar. Biol. Ecol. 87: 153-168

Branch, G. M., Marsh, A. C. (1978). Tenacity and shell shape in six Patella species: adaptive features. J. exp. mar. Biol. Ecol. 34: 111-130

Bulkley, P. T. (1968). Shell damage and repair in five members of the genus Acmaea. Veliger 11 (Supp.): 64-67

Bullock, T. H. (1953). Predator recognition and escape responses of some intertidal gastropods in presence of starfish. Behaviour 5: 130-140

Calow, P. (1974). Some observations on locomotory strategies and their metabolic effects in two species of freshwater gastropods, Ancylus fluviatilis Mull. and Planorbis contortus Linn. Oecologia (Berl.) 16: 149-161 
Capon, R. J., Faulkner, D. J. (1984). Metabolites of the pulmonate Siphonaria lessoni. J. org. Chem. 49: 2506-2508

Chapin, D. (1968) Some observations of predation of Acmaea species by the crab pachygrapsus crassipes. Veliger 11 (Supp.): $67-69$

Cimino, G., DeRosa, S., DeStefano, S., Sodano, G. (1982). The chemical defense of four Mediterranean nudibranchs. Comp. Biochem. Physiol. 73B: 471-474

Cook, S. B. (1979). Fish predation on pulmonate limpets. Veliger 22: $380-381$

Dayton, P. K. (1971). Competition, disturbance, and community organization: the provision and subsequent utilization of space in a rocky intertidal community. Ecol. Monogr. 41: $\mathbf{3 5 1 - 3 8 9}$

Denny, M. (1980). Locomotion: The cost of gastropod crawling. Science, N. Y. 208: 1288-1290

Dethier, M. N. (1984). Disturbance and recovery in intertidal pools: maintenance of mosaic patterns. Ecol. Monogr. 54: 99-118

Eaton, C. M. (1968). The activity and food of the file limpet Acmaea limatula. Veliger 11 (Supp.): 5-12

Faulkner, D. J., Ghiselin, M. T. (1983). Chemical defense and evolutionary ecology of dorid nudibranchs and some other opisthobranch gastropods. Mar. Ecol. Prog. Ser. 13: 295-301

Feare, C. J. (1971). Predation of limpets and dogwhelks by oystercatchers. Bird Study 18: 121-129

Feder, H. M. (1963). Gastropod defense responses and their effectiveness in reducing predation by starfishes. Ecology 44: $505-512$

Frank, P. W. (1981). A condition for a sessile strategy. Am. Nat. 118: 288-290

Garrity, S. D., Levings, S. C. (1983). Homing to scars as a defense against predators in the pulmonate limpet Siphonaria gigas (Gastropoda). Mar. Biol. 72: 319-324

Hartwick, E. B. (1976). Foraging strategy of the black oyster catcher (Haematopus bachmani Audubon). Can. J. Zool. 54: $142-155$

Hochlowski, J. E., Coll, J. C., Faulkner, D. J., Biskupiak, J. E. Ireland, C. M., Qi-tai, Z., Cun-heng, H., Clardy, J. (1984) Novel metabolites of four Siphonaria species. J. Am chem. Soc. 106: 6748-6750

Hochlowski, J. E., Faulkner, D. J. (1983). Antibiotics from the marine pulmonate Siphonaria diemenensis. Tetrahedron Lett. 24: 1917-1920

Hochlowski, J. E., Faulkner, D. J. (1984). Metabolites of the marine pulmonate Siphonaria australis. J. org. Chem. 49: 3838-3840

Hochlowski, J. E., Faulkner, D. J., Matsumoto, G. K., Clardy, J. (1983). The denticulatins, two polypropionate metabolites from the pulmonate Siphonaria denticulata. J. Am chem. Soc. 105: 7413-7415

Ireland, C., Faulkner, D. J. (1978). The defensive secretion of the opisthobranch mollusc Onchidella binneyi. Bioorg. Chem. 7: 125-131

Johnston, R. F. (1954). The summer food of some intertidal fishes of Monterey County, California. Calif. Fish Game 40: $65-68$

Lindberg, D. R., Chu, E. W. (1982). Western gull predation on owl limpets: different methods at different localities. Veliger 25: $347-348$
Lowell, R. B. (1984). Desiccation of intertidal limpets: effects of shell size, fit to substratum, and shape. J. exp. mar. Biol. Ecol. 77: 197-207

Mauzey, K. P., Birkeland, C., Dayton, P. K. (1968). Feeding behavior of asteroids and escape responses of their prey in the Puget Sound region. Ecology 49: 603-619

Mitchell, D. F. (1953). An analysis of stomach contents of California tide pool fishes. Am. Midl. Nat. 49: 862-871

Morris, R. H., Abbott, D. P., Haderlie, E. C. (1980). Intertidal invertebrates of California. Stanford Univ. Press, Stanford

Okuda, R. K., Scheuer, P. J., Hochlowski, J. E., Walker, R. P., Faulkner, D. J. (1983). Sesquiterpenoid constituents of eight porostome nudibranchs. J. org. Chem. 48: 1866-1869

Phillips, D. W. (1975). Distance chemoreception-triggered avoidance behavior of the limpets Acmaed (Collisella) limatula and Acmaea (Notoacmaea) scutum to the predatory starfish Pisaster ochraceus. J. exp. Zool. 191: 199-210

Phillips, D. W. (1976). The effect of a species-specific avoidance response to predatory starfish on the intertidal distribution of two gastropods. Oecologia (Berl.) 23: 83-94

Rice, S. H. (1985). An anti-predator chemical defense of the marine pulmonate gastropod Trimusculus reticulatus (Sowerby). J. exp. mar. Biol. Ecol. 93: 83-89

Seapy, R. R. (1966). Reproduction and growth in the File Limpet, Acmaea limatula Carpenter, 1984 (Mollusca: Gastropoda). Veliger 8: 300-310

Shanks, A. L., Wright, W. G. (1986). Adding teeth to wave action: the destructive effects of wave-borne rocks on intertidal organisms. Oecologia (Berl.) (in press)

Sokal, R. R., Rohlf, F. J. (1981). Biometry. 2nd edn. W. H. Freeman and Co., San Francisco

Sousa, W. P. (1979). Disturbance in marine intertidal boulder fields: the nonequilibrium maintenance of species diversity. Ecology 60: 1225-1239

Southward, A. J., Orton, J. H. (1954). The effects of waveaction on the distribution and numbers of the commoner plants and animals living on the Plymouth breakwater J. mar. biol. Ass. U. K. 33: 1-19

Stephens, J. S., Johnson, R. K., Key, G. S., McCosker, J. E $(1970)$. The comparative ecology of three sympatric species of California blennies of the genus Hypsoblennius Gill (Teleostomi, Blenniidae). Ecol. Monogr. 40: 213-233

Still, W. C., Kahn, M., Mitra, A. (1978). Rapid chromatographic technique for preparative separations. J. org. Chem. 43: 2923-2925

Stobbs, R. E. (1980). Feeding habits of the giant clingfish Chorisochimus dentex (Pisces: Gobiesocidae). S. Afr. J Zool. 15: 146-149

Thompson, T E. (1960). Defensive acid-secretion in marine gastropods. J. mar. biol. Ass. U. K. 39: 115-122

Vermeij, G. J. (1978). Biogeography and adaptation. Harvard University Press, Cambridge, Massachusetts

Wells, R. A. (1980). Activity pattern as a mechanism of predator avoidance in two species of acmaeid limpet. J. exp. mar Biol. Ecol. 48: 151-168

Wolcott, T G. (1973). Physiological ecology and intertidal zonation in limpets (Acmaea): a critical look at "limiting factors" Biol. Bull. mar. biol. Lab., Woods Hole 145 $389-422$ 